\title{
Faculty Perceptions of Using Synchronous Video-based Communication Technology
}

\author{
Patrick R. Lowenthal \\ Boise State University, USA \\ Richard E. West \\ Brigham Young University, USA \\ Leanna Archambault \\ Arizona State University, USA \\ Jered Borup \\ George Mason University, USA \\ Eric S. Belt \\ University of Maryland, Baltimore, USA
}

\begin{abstract}
Online learning has traditionally relied on asynchronous text-based communication. The COVID19 pandemic, though, has provided many faculty members with new and/or additional experience using synchronous video-based communication. Questions remain, though, about how this experience will shape online teaching and learning in the future. We conducted a mixed method study to investigate faculty perceptions of using synchronous video-based communication technology. In this paper, we present the results of our inquiry and implications for future research and practice.
\end{abstract}

Keywords: Synchronous learning, synchronous teaching, synchronous video, synchronous videobased communication, web-conferencing, asynchronous video

Lowenthal, P., West, R.E., Archambault, L., Borup, J., \& Belt, E. S. (2021). Faculty perceptions of using synchronous video-based communication technology. Online Learning, 25(4), 74-103. DOI: $10.24059 /$ olj.v25i4.2890 
The COVID-19 pandemic forced colleges and universities to move in-person courses online (Hodges et al., 2020). With little time, few resources, and often limited experience teaching at a distance, many faculty members opted to replace in-person class sessions with synchronous online meetings using web conferencing tools like Zoom (Lederman, 2020a, 2020b). This is not surprising. Over the last few years, faculty members increasingly attended or facilitated online meetings or webinars, familiarizing them with web conferencing tools like Zoom (Liu \& Alexander, 2017). Further, replacing an in-person class with a synchronous online meeting requires little extra preparation. Research has also identified affordances of using synchronous meetings in blended and online courses such as improving immediacy, social presence, and a sense of community (Lowenthal et al., 2017; McDaniels et al., 2016; Martin \& Parker, 2014; Park \& Bonk, 2007). However, despite the convenience and possible benefits, there are constraints with the use (and overuse) of synchronous meetings. These include finding a convenient time, dealing with broadband and technical issues, and the tendency for synchronous meetings to turn into long lectures (Flaherty, 2020; Lederman, 2020b; Lowenthal et al., 2020).

Prior to COVID-19, many online educators, likely aware of some of the benefits and constraints, were resistant to using synchronous meetings in their online courses (Liu \& Alexander, 2017; Themelis, 2014). Among others, Themelis (2014) and Liu and Alexander (2017) found that a lack of institutional support and training on synchronous communication technologies created barriers to teaching from a distance, including reducing online educators' confidence, self-efficacy, and motivation related to synchronous technology. However, COVID19 and the requirement to teach and work from a distance, introduced faculty members to synchronous video-based communication technology for the first time and/or gave many others opportunities to experience it in new ways (Flaherty, 2020; Stewart, 2021). Questions remain, however, about how teaching and working from home might influence the ways faculty members will work and teach in the future, especially in regards to their communication and interaction with students and colleagues (see de Oliveira Dias et al., 2020; Kim, 2020; Pokhrel \& Chhetri, 2021). Given this, we set out to investigate faculty perceptions of synchronous video-based communication technology. In this paper, we present the results of our study and implications for future research and practice. The research questions driving our inquiry were:

1. What are faculty perceptions of using synchronous video-based communication for personal use, teaching and learning, and for non-teaching work purposes?

2. Have faculty perceptions of using communication technologies changed as a result of the COVID-19 pandemic?

\section{Evolution of Distance Education}

\section{Literature Review}

While many instructors and students were first introduced to online learning as a result of COVID-19, distance education dates to the 1800s in the form of correspondence study where students worked through lessons on their own and then mailed them to be corrected (Bower \& Hardy, 2004). In these early days, distance education focused on enabling learners to learn at any place and time. However, as technology advanced, educators increasingly used broadcasting methods, such as radio in the 1920s and television in the 1950s, for distance education (Casey, 2008; Saba, 2011). Broadcasting forms of distance education still focused on enabling people to 
learn from anywhere (i.e., assuming they had access to the broadcast), but did not center on learning at any time. Learner-instructor interactions were thus limited by few, if any, opportunities for learners to interact with their peers.

During the 1980s educators began exploring how to use computer networks and the internet to help people, even at a distance, learn together in ways previously unavailable in terms of more immediate communication between instructor and learner and new opportunities for learner-learner interactions (Harasim, 2000; Moore, 1989). By the 1990s, distance education had moved predominantly online. While the term "online learning" is used to describe the mode of communication, Garrison (2009) stressed that online learning and distance education have different core values. Specifically, distance education core values are access and flexibility while online learning's core values are collaborative learning and other constructivist approaches to learning.

These early online courses relied heavily, if not solely, on asynchronous text-based communication (i.e., email and discussion boards) and were often described as asynchronous learning networks (see Mayadas, 1997). Proponents highlighted the ability of people to learn from anywhere at any time while maintaining contact with other learners. While asynchronous online learning continued to grow and has since become the most common form of learning online, educators have continued to use broadcast methods as well as other forms of synchronous methods of communication (e.g., instant messaging, web conferencing) to teach and learn online (Finkelstein, 2006). Recently, Florence et al. (2020) defined the practice of combining synchronous and asynchronous online learning as bichronous learning. Online educators, though, need to understand the affordances and constraints of asynchronous and synchronous online communication and how best to strategically combine the two.

\section{Asynchronous vs. Synchronous Communication}

Various forms of online learning are often distinguished by how frequently instructors and students meet in person as well as the degree to which they rely on asynchronous or synchronous communication. For instance, Allen and Seaman (2007) distinguished between traditional, web facilitated, blended/hybrid, and online courses. A few years later, Sener (2015) described seven types of courses: (1) classroom course, (2) synchronous distributed course, (3) web-enhanced course, (4) blended classroom course, (5) blended online course, (6) online course, and (7) flexible mode course. COVID-19 helped popularize a distinction between remote courses, where an instructor and students meet regularly online at a certain day and time (e.g., in synchronous sessions) and online courses designed to be completed primarily in an asynchronous format (Craig, 2020; Roe, 2020).

\section{Affordances and Constraints of Asynchronous and Synchronous Communication}

No communication medium is perfect but researchers spent the 1990s comparing various learning media for any inherent superiority. Those studies ultimately suggested that asynchronous and synchronous communication each have affordances and constraints, and that it matters more what one does with a communication medium than any inherent constraints (Hrastinski, 2008; Oztok et al., 2013). However, asynchronous communication was, and still is, the dominant form of communication in online courses (Oztok et al., 2013; Peterson et al., 2018). Asynchronous communication enables instructors and students to interact and communicate from any place or time. The flexibility in time inherent in asynchronous communication also affords the ability of time-independent access, equal opportunities to participate, improved peer interaction and participatory learning, time for reflection, and the ability to have in depth discussions over time (Garrison et al., 2000; Graham, 2006; McDonald, 2016; Oztok et al., 
2013). Despite these benefits, asynchronous text-based communication has been criticized for the time it takes conversations to develop, its lack of spontaneity, being too task-based, offering insufficient opportunities for social interactions, creating a sense of isolation or separation between participants, and delaying communication and feedback (Graham, 2006; Hrastinski, 2008; Huang \& Hsiao, 2012; Romero-Hall \& Vicentini, 2017). Further, criticisms of online learning often focus on the absence of body language and visual cues in asynchronous text-based communication (Lowenthal, 2010).

Educators have been attracted to synchronous communication, and specifically synchronous video-based communication, because it most closely resembles in-person communication (Lowenthal et al., 2020; Romero-Hall \& Vicentini, 2017). More specifically, researchers have argued that synchronous sessions help improve teacher immediacy, improve interaction and student participation, and enable spontaneity (Hrastinski, 2008; Olson, 2015; Park \& Bonk, 2007; Parker \& Martin, 2010). However, synchronous communication also has constraints, many of which were identified long before COVID-19. For example, it can be difficult in synchronous meetings to enable equal participation. Such meetings are prone to distraction, can be plagued by technical difficulties, and often have privacy and security issues (Bali, 2016; West \& Borup, 2021; Means \& Neisler, 2021). Bali and Meier (2014) even argue that synchronous meetings can be biased and culturally unaware, and can favor those with flexible time schedules, who live in popular time zones, have reliable wifi, and possess linguistic capital. These constraints have been amplified in various ways during COVID-19 with the increased day-to-day use of synchronous meetings. However, this increase has also resulted in people suffering from "Zoom fatigue" (Caines, 2020; Schulman, 2020).

\section{Changes in Perceptions and Use Over Time}

Perceptions of asynchronous and synchronous communication have evolved over time. During the late 1990s and early 2000s, online educators often questioned the need and value of synchronous communication (see Palloff \& Pratt, 1999). But by the mid-to-late 2000s, as web conferencing applications and broadband improved, a growing group of online educators began experimenting more with using synchronous communication, often in primarily asynchronous online courses (Hrastinski, 2008; Hrastinski et al., 2010; Park, \& Bonk, 2007). By 2014, Cornelius (2014) and Martin and Parker (2014) both noted the increased use of synchronous meetings in higher education. More recently, Lemos dos Santos and Cechinel (2019) found that instructors and students had a clear preference for asynchronous communication tools but synchronous communication tools also received high rankings. Following these perceived preferences, educators have increasingly used synchronous meetings as a supplement to asynchronous learning activities, although perhaps not as much as some might have predicted, considering their widespread availability. This lack of widespread use, prior to COVID-19, could have been due in part to a lack of opportunities and training to learn how to effectively use synchronous meetings (Grant \& Cheon, 2007; Martin \& Parker, 2014). However, Ertmer's (1999) framework on obstacles to change highlights that the lack of training is only one of several reasons why instructors fail to adopt new teaching practices, even when those practices have the potential to positively impact course outcomes and that a more deeply rooted obstacle is faculty's beliefs, attitudes, and dispositions that can make them especially resistant to new ways of teaching and learning.

Faculty Resistance to Online Learning and Unintended Consequences of COVID-19

Enrollments in online courses and programs in higher education continued to grow during the last decade (Allen \& Seaman, 2017). Before COVID-19, a third of students took at least one 
online course each year (Allen \& Seaman, 2018; Lederman, 2018). Despite the growth in online learning, the majority of faculty remained skeptical of online learning and even resisted teaching online (Jaschik \& Lederman, 2016; Lloyd et al., 2012). The literature suggests that faculty may resist teaching online because of concerns about interaction and student outcomes, lack of institutional support, training requirements, workload concerns, and fear of losing control (Allen et al., 2012; Lloyd et al., 2012; McGee, et al., 2017; Ubell, 2017). At the same time, research also suggests that these concerns are less prevalent with faculty members who have prior experience teaching in blended and online learning formats (Hunt et al., 2014; Lloyd et al., 2012).

While COVID-19 has been disruptive to the field of education, it forced nearly every educator to gain some general experience with digital instruction, if not specifically with remote or online teaching. Before COVID-19, instructors like Christopher Schaberg (2018) boldly claimed "I'll never teach online." However, during COVID-19, many instructors like Schaberg (2020) chose to teach online even when they could teach in-person. And still others, such as Eric Mazur, an "active-learning evangelist" and "teaching celebrity," now question whether teaching online might even be better than teaching in-person (McMurtie, 2021).

In summary, distance education has evolved over the years. Even before COVID-19, colleges and universities offered several types of blended and online courses. While these blended and online courses tended to rely on asynchronous text-based communication, instructors have used synchronous sessions in various ways. During the pandemic, nearly every faculty member had an opportunity to work and teach from a distance, often using synchronous sessions in unprecedented ways. These new experiences may change online learning and the nature of faculty work in the future. However, additional research is needed to find out how these experiences might have influenced faculty perceptions of synchronous meetings as well as their perceptions of blended and online learning.

\section{Method}

After receiving Institutional Review Board approval (protocol 101-SB20-103), we conducted an explanatory, two-phased, sequential, mixed-methods study (Onwuegbuzie \& Leech, 2005). This research design was used so that follow-up interviews could help explain or elaborate on the results from the first phase of the study. We were interested in a better understanding of faculty perceptions of synchronous video-based communication technology.

\section{Data Collection}

We created an online survey using Qualtrics to collect data during the first phase of the study. The survey included a series of Likert-style questions (on a 5-point scale) as well as openended questions that provided an opportunity for participants to explain their responses and to take part in a follow-up interview (a copy of the survey and interview questions are in the Appendix). The survey was administered via Facebook, Twitter, and various professional organizations (e.g., WCET, EDUCAUSE, AERA AECT, SITE), as well as to all faculty members at two Colleges of Education where two of the researchers work. A total of 336 people completed the survey.

The second phase of the study involved follow-up interviews. A total of 40 participants agreed to be interviewed. From this list, we randomly selected 15 participants to interview but added 3 additional interviews (for a total of 18) due to delays in setting up the original interviews. The semi-structured interviews were conducted by Belt and recorded in Zoom. 


\section{Data Analysis}

Descriptive statistics were calculated for the quantitative survey questions. The qualitative data from the open-ended survey questions were analyzed using a constant comparative technique (Leech \& Onwuegbuzie, 2007) which essentially involved using a multistage coding process of descriptive and pattern coding to code and analyze the data (Saldana, 2016). Descriptive coding "summarizes in a word or short phrase - most often as a noun - the basic topic of a passage of qualitative data" (Saldana, 2013, p. 88). Pattern coding is a way of grouping those summaries into a smaller number of sets, themes, or constructs (Miles \& Huberman, 1994). Then the recordings from the follow-up interviews were transcribed and coded following the same multistage coding process.

\section{Positionality, Trustworthiness, and Credibility}

The first author, Lowenthal, initially conceived of the study. While he collaborated with his co-authors to create the survey and interview questions, conduct the study, and write up the results, he oversaw qualitative data analysis. He is an experienced researcher and an online educator since 2003. He has interest in, and experience with, various teaching and learning communication technologies. However, he also believes that no communication technology is inherently better than another, and that video is not a panacea and should be used intentionally and selectively (see Belt \& Lowenthal, under review; Belt \& Lowenthal, 2021; Lowenthal, under review; Lowenthal, 2021; Lowenthal et al., 2020; Lowenthal et al., 2022; Lowenthal \& Moore, 2020). He approached this study with an interest in better understanding how faculty experiences during COVID-19 might influence their perceptions and future use of synchronous video-based communication technology and, in turn, its influence on the future of online learning.

Lowenthal initially analyzed the qualitative data from surveys and interviews after Belt conducted the interviews. He compared the data and themes that emerged from both the surveys and the interviews as a form of triangulation. Then, following the advice of Elo et al. (2014), who explained that "a good qualitative researcher cannot avoid ... returning again and again to the data, to check whether the interpretation is true to the data and the features identified are corroborated by other interviews" (p. 5), he returned to the data three months after the initial analysis, and with questions prompted by his co-authors, to double-check his analysis and in turn improve the reliability and credibility of the initial analysis.

\section{Findings}

\section{Phase One: Survey Results Part One: Demographics}

Participants' teaching experience in higher education ranged from 1 to 30 years, with an average of 12.7 years $(\mathrm{SD}=8.1)$; their experience teaching blended or online courses in higher education ranged from 1 to 26 years, with an average of 8.12 years $(\mathrm{SD}=6.0)$. We asked participants how frequently they used synchronous video-based communication before COVID19 in other parts of their lives (see Table 1). We found that participants who might be described as "regular users" (i.e., those who use it daily, weekly, or monthly) used synchronous meetings more for work not focused on teaching as well as for their personal life and less for teaching. However, over $28 \%$ had rarely or never used it for work not related to teaching and over $45 \%$ had not used it when teaching a blended or online course prior to COVID-19. 
Table 1

Synchronous Video-based Communication Use Before COVID-19

\begin{tabular}{|c|c|c|c|c|c|c|c|}
\hline $\begin{array}{l}\text { Before COVID-19, how } \\
\text { frequently did you use } \\
\text { synch. comm. }\end{array}$ & Daily & Weekly & Monthly & $\begin{array}{c}\text { 1-2 times a } \\
\text { semester }\end{array}$ & Rarely & Never & $\mathbf{n}$ \\
\hline Personal life & $16(4.8 \%)$ & $68(20.5 \%)$ & $61(18.4 \%)$ & $32(9.7 \%)$ & $102(30.8 \%)$ & $52(15.7 \%)$ & 331 \\
\hline For work not teaching & $32(9.6 \%)$ & $95(28.6 \%)$ & $68(20.5 \%)$ & $43(13 \%)$ & $66(19.9 \%)$ & $28(8.4 \%)$ & 332 \\
\hline Teaching a blended or online & $18(6.4 \%)$ & $66(20.2 \%)$ & $38(11.6 \%)$ & $54(16.51 \%)$ & $50(15.3 \%)$ & $98(30.0 \%)$ & 324 \\
\hline When teaching F2F & $6(1.9 \%)$ & $13(4.1 \%)$ & $10(3.1 \%)$ & $36(11.3 \%)$ & $85(26.7 \%)$ & $168(52.8 \%)$ & 318 \\
\hline
\end{tabular}

\section{Part Two: Satisfaction}

Once we knew how often participants used synchronous meetings in different aspects of their life, we wanted to know how satisfied they were teaching blended and online courses before COVID-19 and specifically how satisfied they were with using synchronous video-based communication during the pandemic. Overall, 76\% of participants (who had taught blended or online courses before COVID-19) were somewhat or extremely satisfied with teaching blended or online courses. Similarly, $76 \%$ of participants reported that they were either somewhat satisfied or extremely satisfied with using video-based communication in their personal life, $77 \%$ were either somewhat satisfied or extremely satisfied with using it for teaching and learning, and $85.5 \%$ were either somewhat satisfied or extremely satisfied with using it for work not related to teaching and learning (see Table 2).

Table 2

Satisfaction With Teaching Blended / Online Courses Before COVID-19 and Use of Synchronous Video-based Communication During COVID-19

$\begin{array}{cccccccc}\mathbf{1} & \mathbf{2} & \mathbf{3} & \mathbf{4} & \mathbf{5} & \boldsymbol{M} & \mathbf{S D} & \mathbf{n} \\ \begin{array}{c}\text { Extremely } \\ \text { dissatisfied }\end{array} & \begin{array}{c}\text { Somewhat } \\ \text { dissatisfied }\end{array} & \begin{array}{c}\text { Neither } \\ \text { satisfied nor } \\ \text { dissatisfied }\end{array} & \begin{array}{c}\text { Somewhat } \\ \text { satisfied }\end{array} & \begin{array}{c}\text { Extremely } \\ \text { satisfied }\end{array} & & & \\ \end{array}$

Before COVID-19, how $7(2.4 \%) \quad 31(10.4 \%) \quad 34(11.4 \%) \quad 114(38.4 \%) \quad 111(37.8 \%) 3.98 \quad 1.06297$ satisfied were you teaching blended/online?*

Currently, how satisfied are you with synchronous video-based communication...

\begin{tabular}{|c|c|c|c|c|c|c|}
\hline in your persona & $(1.8 \%)$ & $20(6 \%)$ & $53(15.9 \%)$ & $136(40.7 \%)$ & $119(35.6 \%)$ & \\
\hline & $6(1.8 \%)$ & $29(8.7 \%)$ & $42(12.6 \%)$ & $178(53.5 \%)$ & $78(23.4 \%)$ & 3.8 \\
\hline . & $2(0.6 \%)$ & $12(3.6 \%)$ & $35(10.4 \%)$ & $141(42 \%)$ & $146(43.5 \%)$ & \\
\hline
\end{tabular}

*Note: 38 or $10 \%$ of participants had not taught blended or online prior to COVID

We then asked participants to explain their responses related to their current use (see Table 2). Six themes were identified from the data from this question (see Table 3). We briefly discuss each below and include some verbatim quotations from various respondents.

Convenience and Flexibility. Participants reported that they were happy with the convenience and flexibility of using synchronous video-based communication. They specifically 
liked not having to drive to campus for meetings and the convenience and flexibility this type of communication can provide.

I honestly love working from home and not...traveling...to attend things in person. This has made my work life far less taxing.

The way synchronous time is used makes a huge difference. Shorter synchronous time is better...

Overuse and Fatigue. Participants consistently commented on the overuse of synchronous video-based communication and the fatigue that they can feel from spending hours at a time in meetings.

I actually have more meetings now over Zoom than I used to when working in the office. I think we've adopted the mentality that since we can't pop in and talk in the office, we need to schedule extra meetings, but it's left me...exhausted and Zoomed out (something that's no doubt exacerbated by having two small children at home).

I'm definitely feeling Zoom fatigue in both my professional and personal life.... I don't feel eager to use it in my personal life largely because I'm using it so much for work... it beats the alternative of not being able to work/collaborate remotely...my beef is with the pandemic more than with Zoom.

Personal video calls are becoming tiring due to doing so many of them in the pandemic. I wish that we didn't have to do them and could just meet in person. My distaste is emotional, not technical; the technology is fine, I just tire of it.

User Interaction, Engagement, and Multi-tasking \& Distraction. Another theme focused on the lack of user interaction, engagement, and multitasking, and the distraction that takes place in these meetings. Participants pointed out problems and the frustration of being in meetings where group members have their cameras off, seem disengaged, and appear to be doing other things. This theme is illustrated in the following quotes:

It's not bad, but I miss actually SEEING the people...I am frustrated with students not turning on their cameras (even though I completely understand why, and I respect their right to *not* turn them on). But still, I don't like that, to be honest. In committee meetings: I don't mind online meetings. Saves time. I have a hate on for admin work recently.

One-on-one or small group video chats with friends and family work well-everyone is happy to participate, we get to see each other... With teaching, the students mostly have black screens and are reluctant to participate. For work, it's fine... where I am not expected to participate, I often turn off video and fold laundry or go for a walk (I realise [sic] my students may think of video classes in these terms) - there are a few questions after such lectures, but it might almost just as well have been pre-recorded. 
Learning Curve and Technical Issues. Consistently, participants identified a learning curve, both in terms of comfort with the technology and with its effective use. In addition, participants described how institutions must continue to find ways to support faculty and student use of this type of communication because, regardless of one's skills and abilities with the technology, technical problems arise (sometimes due to students' lack of knowledge) that can derail a lesson and even be emotionally taxing. Here are several perspectives:

I still feel like I lack the skills to effectively foster quality discussions where everyone feels involved in class (teaching). Similar feelings for hosting large-and medium-sized family/personal groups. It always feels just a bit awkward and like there are some who are not speaking up. Also, I'd like to learn how to use various other tools ... but I feel like I just don't have the time or energy.

In a research collaboration context, it's easier to navigate minor technical hiccups, and because there are fewer of us, they don't happen very often. In a teaching context, it's very stressful to manage the experience of 20-50 students...technical glitches are emotional. They mean missing important parts of the story or key events. It's worse to have a bad connection than to not have participated remotely in the first place.

With family it's even worse. God bless my in-laws and their complete inability to remember how to log on from one weekend to the next. By the time we are all connected, I'm so irritated I don't even want to be online anymore.

Context, Purpose, People, and Technology. The last theme focused on how many things can impact the effectiveness of a synchronous meeting. Participants pointed out how they thought synchronous meetings worked better for smaller groups and shorter meetings than larger groups and longer meetings. They also mentioned that they thought they worked better when people wanted to be there, wanted to participate and contribute (e.g., committee work), and had a previously established relationship with other attendees. And finally, the effectiveness of synchronous meetings can be impacted by the platform, as some participants clearly preferred some platforms over others. The following quotes capture some of these ideas:

I find it very difficult to...connect to my students, especially those I have not met in faceto-face contexts. For research \& admin purposes-these are...people I have likely met before and already have a connection to.

I think meeting online is necessary but not ideal for building relationships."

Zoom works well for small meetings or large webinars, but the middle ground of classroom-like gatherings isn't perfect. It takes so much energy to corral more than seven people on a Zoom meeting, and it ends up being less discussion, more presentation. 
Zoom works well for small meetings with colleagues that are both interested in the subject matter and willing participants in the meeting .... From my limited experience,

Zoom synchronous online teaching (any class over 20 students) with tools like Zoom is a dark pit where students just sit there zoning out; not participating and generally wasting their time.

Table 3

Themes of Factors That Influenced Satisfaction

\section{Convenience and Flexibility}

Overuse and Fatigue

User Interaction, Engagement, and Multi-tasking \& Distraction

\section{Learning Curve}

\section{Technical Issues}

Context, Purpose, People, and Technology
Participants repeatedly reported that they like how video-based synchronous technology enables them to work from a distance, especially during a pandemic, and the ability to connect with friends, family, and colleagues from all over the world.

Participants mentioned how the convenience and flexibility of video-based synchronous technology has resulted in more meetings, with many faculty being required to add synchronous meetings to their "remote" courses. The increasing number of synchronous meetings has resulted in what many referred to as "Zoom fatigue."

Participants pointed out challenges of ensuring every participant is able to interact and are engaged during video-based synchronous meetings or classes; common practices of turning one's camera off or multitasking during work meetings or class can lead to distraction or the instructor's inability to check student understanding.

Participants noted that there is a learning curve to effectively using videobased synchronous technology and that faculty and students, as well as friends and family, need time, experience, and resources to be able to effectively use these communication tools.

Participants repeatedly pointed out how technical issues, whether they be due to bandwidth issues (including audio and visual latency issues), platform technical glitches, or user error, can influence how satisfied they are with video-based synchronous technology.

Participants also pointed out that the context (e.g., group size, length), the purpose (e.g., socializing vs. committee work; office hours vs. full class), the people (e.g., with a previously established relationship), and the technology influenced their level of satisfaction with using video-based synchronous technology.

\section{Part Three: Satisfaction with Other Communication Technologies}

Once we had an idea about how satisfied participants were with synchronous video-based communication, we wanted to better understand how satisfied they were with using other communication technologies when teaching blended or online courses. Not surprisingly, participants expressed highest satisfaction with email $(M=4.06)$ but synchronous meetings/discussions were a close second $(M=3.96)$. Phone calls $(M=3.40)$, text messaging $(\mathrm{M}=3.50)$, and group messaging $(M=3.50)$ received the lowest ratings (see Table 4$)$. 
Table 4

Satisfaction With Different Types of Communication Technology When Teaching Blended and Online Courses

\begin{tabular}{cccccccc}
$\mathbf{1}$ & $\mathbf{2}$ & $\mathbf{3}$ & $\mathbf{4}$ & $\mathbf{5}$ & $\boldsymbol{M}$ & SD & $\mathbf{n}$ \\
$\begin{array}{c}\text { Extremely } \\
\text { dissatisfied }\end{array}$ & $\begin{array}{c}\text { Somewhat } \\
\text { dissatisfied }\end{array}$ & $\begin{array}{c}\text { Neither } \\
\text { satisfied nor } \\
\text { dissatisfied }\end{array}$ & $\begin{array}{c}\text { Somewhat } \\
\text { satisfied }\end{array}$ & $\begin{array}{c}\text { Extremely } \\
\text { satisfied }\end{array}$ & & & \\
& & & & & & \\
\hline
\end{tabular}

\begin{tabular}{lcccccccc}
\hline \multicolumn{7}{l}{ How satisfied are you with using when teaching blended or online courses? } \\
$\begin{array}{lllllllll}\text { Email } & 10(3.2 \%) & 12(4 \%) & 39(12.4 \%) & 143(45.5 \%) & 110(35 \%) & 4.05 & 0.96 & 314 \\
\text { Phone call } & 22(8.5 \%) & 36(14 \%) & 80(30.9 \%) & 64(24.7 \%) & 57(22.0 \%) & 3.38 & 1.21 & 259 \\
\text { Text message (to one person) } & 19(8 \%) & 26(11 \%) & 66(27.7 \%) & 76(31.9 \%) & 51(21.4 \%) & 3.48 & 1.18 & 238 \\
\begin{array}{l}\text { Group text or messaging } \\
\text { (e.g., Slack) }\end{array} & 15(6.7 \%) & 18(8 \%) & 74(33.2 \%) & 77(34.5 \%) & 39(17.5 \%) & 3.48 & 1.08 & 223 \\
\begin{array}{l}\text { Asynchronous text-based } \\
\text { discussions (e.g., in an LMS) }\end{array} & 12(3.8 \%) & 40(13 \%) & 36(11.4 \%) & 144(45.7 \%) & 83(26.3 \%) & 3.78 & 1.09 & 315 \\
\begin{array}{l}\text { Asynchronous video-based } \\
\text { discussions (e.g., Flipgrid) }\end{array} & 4(1.7 \%) & 13(6 \%) & 75(32.8 \%) & 92(40.2 \%) & 45(19.7 \%) & 3.70 & 0.91 & 229 \\
\begin{array}{l}\text { Synchronous video-based } \\
\text { discussions (e.g., Zoom) }\end{array} & 6(1.9 \%) & 25(8 \%) & 27(8.7 \%) & 175(56.1 \%) & 79(25.3 \%) & 3.95 & 0.91 & 312\end{array}$ \\
\hline
\end{tabular}

\section{Part Four: COVID's Influence}

We then investigated how participants experienced social distancing and how working and teaching at home might influence their future use of synchronous video-based communication. Participants overall reported that they were more likely to use video-based technology in all facets of their life after COVID-19 (see Table 5). However, there was even stronger agreement when asked about using it for work not related to teaching $(M=4.19)$ and when teaching a blended or online course $(M=4.06)$.

Table 5

Likelihood of Future Use of Video-based Communication

$\begin{array}{cccccccc}\mathbf{1} & \mathbf{2} & \mathbf{3} & \mathbf{4} & \mathbf{5} & \mathbf{M} & \text { SD } & \mathbf{n} \\ \begin{array}{c}\text { Strongly } \\ \text { disagree }\end{array} & \begin{array}{c}\text { Somewhat } \\ \text { disagree }\end{array} & \begin{array}{c}\text { Neither } \\ \text { agree nor } \\ \text { disagree }\end{array} & \begin{array}{c}\text { Somewhat } \\ \text { agree }\end{array} & \begin{array}{c}\text { Strongly } \\ \text { agree }\end{array} & & & \end{array}$

\footnotetext{
To what degree do you agree with the following: Once the COVID-19 pandemic ends, I'm more likely to use synchronous video-based communication (e.g., Zoom, WebEx)... than before the pandemic

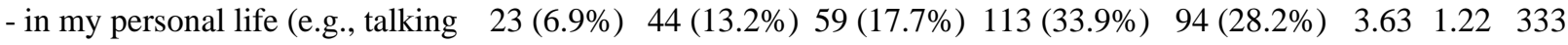
with friends or family)

$\begin{array}{lllllllll}\text { - for work not related to teaching } & 6(1.8 \%) & 13(4 \%) & 44(13.4 \%) & 114(34.8 \%) & 151(46 \%) & 4.19 & 0.94 & 338\end{array}$ and learning (e.g., research

collaboration, advising, committee work)

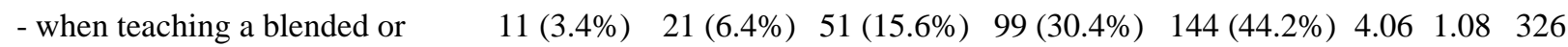
online course
} 
We then asked participants to explain their answers about their future use. We identified five themes, listed in Table 6, discussed briefly here.

More Likely to Use for Work. Echoing the results in Table 5 and certain themes from earlier, some participants described how they were more likely to use video-based technology for work that was not focused on teaching. As participants gained more experience with synchronous meetings at work, they grew to appreciate the increased comfort and/or efficiencies of attending work or advising meetings online. The following quotes capture this sentiment:

Previous beliefs that working and collaborating face-to-face were more effective... have shifted dramatically. We have learned that online, synchronous communications are just as effective. We can ...can accomplish the same, if not more, working ...online instead of spending time to commute. Additional benefits...less pollution, less time wasted in traffic...less overhead...

For work, I will continue to use synchronous video-based communication for everything - as much as I can. I find it effective and flexible. Also considering the state of the world, I do not feel comfortable venturing out into public anytime soon.

Now that more people are familiar with Zoom and WebEx, I will likely recommend using it, especially when busy schedules and geographic differences impede meeting in person.

More Likely to Use for Teaching. Other participants expected to use more video-based technology for teaching in the future, citing immediacy, flexibility, and the ability to check-in as needed as reasons.

Zoom has proven to be an effective tool. As such, I am considering using it in conjunction with traditional face-to-face classes.

My online asynchronous students are demanding the use of synchronous instruction--I imagine my F2F students will seek more of this as well.

I asked my 100\% online students if they would like me to hold an optional synchronous hour each week and they said yes. So, I am implementing this for the first time in the fall.

Unsure or Undecided About Future Use. Some participants expressed uncertainty about future use since they were unsure of what their university, colleagues, and/or students will expect in the future. and when the pandemic will end.

Well...it depends on many factors. So, we'll have to see.

These decisions are not ours to make. It was not up to us to shift everything online ... and it will not be up to us... how things will work once the crisis ends, if such a day ever comes. 
I think it will depend on how the structure of the university and the expectations of students change as a result of the pandemic.

No Change. Some participants had been using synchronous meetings long before COVID-19. They therefore claimed that their experiences using it during the pandemic will not likely change how they use it after COVID-19. They highlighted the importance of taking a balanced approach as captured below:

I don't foresee anything changing with my use of video conferencing. I use it regularly already and will continue to do so.

I have used synchronous teaching for my courses since 2013. I will not be using this technology any more or any less.

Likely Less Use. Some participants clearly expressed a desire to either take a break from video-based technology or to perhaps never have to use it again. They preferred to be back in the classroom and teaching in ways that they think do not require synchronous meetings:

These tools work well, but I look forward to using them less.

I am very uncomfortable with the technology; my students' access has been unreliable and inconsistent, and I simply do not like it.

I will only use Zoom for work when I 100\% have to. I *will not* use video conferencing solutions if I can teach or meet in-person for better experiences.

Remote/online learning are manifestly inferior ways to teach my subject. I will not do so once classroom instruction is available again.

Table 6

Themes About Future Use of Video-based Communication

\section{More likely to use more for work not directly focused on teaching}

\author{
More likely to use more for \\ teaching
}

Unsure or undecided about future use
Many participants explained that they were likely to use synchronous video-based communication more for meetings, committees, and student advising than before COVID-19 either because of people's increased comfort and/or the increased efficiencies (e.g., flexibility, less commuting, more efficient).

Other participants explained how they were likely to use synchronous video-based communication specifically more for teaching, whether that be with face-to-face, blended, or online courses due to its advantages.

Some participants stated that they were unsure about their future use either because they were unsure about future pandemics, university requirements, subjects taught or class size, or people's general need to take a break from video-based communication. 
No change on use

Likely less use
Some participants reported that they plan to use it just like before as needed, taking a balanced and intentional approach or because they are heavy users.

Some participants stated that they plan to use it less because they simply dislike it, they prefer in-person communication, and/or that they simply need a break.

The last question on the survey asked participants about how their experience working and teaching from home during COVID-19 influenced or changed their perceptions of using communication technologies for teaching at a distance. Three themes emerged from the data (see Table 7). While this question was specifically focused on using various communication technologies when teaching at a distance, most participants focused on whether using synchronous meetings had changed their perceptions. A few faculty members mentioned their increased concerns regarding communication technologies

Improved Perceptions. Many participants reported that working and teaching from home forced them to learn how to use various technologies almost overnight. While many still faced challenges and expressed a need to learn more, the experience helped build their confidence. They were surprised at how flexible and convenient certain teaching and learning tasks were and were inspired with how they might teach differently moving forward.

I see these tools as a real blessing! Is it 'the same' as being in the same room with my students? No. But...continuing learning in these flexible ways has been pretty incredible. I've become convinced that breathing the same air should not be the measure of a highquality learning experience.

It's easier and more efficient than I imagined.

Improved my likelihood of teaching courses online in the future and learning more." "I am much less opposed to online learning than before because Zoom allows for a better online experience

Conflating online courses with asynchronous delivery was a mistake. From now on, all my courses, regardless of delivery method, will include synchronous, and likely, online video conferencing.

It has massively broadened my horizon as to the options and advantages, and I will keep using these new tools I learned about.

Did not change perceptions. At the same time, other experienced educators familiar with various communication technologies as well as those who already had strong feelings about the superiority of face-to-face communication reported that COVID-19 did not really change how they thought about using communication technologies for teaching and learning.

Absolutely not. These tools are identical now as they were in January 2020. 
Pretty much the same but I like to see that ... others are more open to using tech for meetings.

I still believe that online teaching, while sometimes necessary, is never as good as the real thing.

Increased concerns. Finally, a small group reported that they now have increased concerns about the use of communication technology for teaching and learning. They found that rather than bring people together, these tools can be divisive and highlight issues of equity and access.

The pandemic has highlighted for me the inequities that face our students and the need for us as faculty to accommodate our students needs to create more equitable learning environments. Reliable internet, adequate hardware and adequate computer skills are just some of the basic areas that students need more support.

Makes me realize how poor they are.

Synchronous learning disadvantages female staff... [with] caring responsibilities... and disadvantages students who live in multi-generational households and have caring responsibilities. Asynchronous learning is fairer and more equitable as it enables all parties involved to participate at a time that suits them-which is often late in the evening when other members of the household are in bed.

Table 7

Themes About How COVID Changed Perceptions About Communication Technologies

Experience improved their Participants explained how being forced to work and teach in a perceptions of distant format improved their perceptions of communication communication technologies technologies for multiple reasons, the most popular being: (a) providing needed experience and practice to build confidence, (b) general ease, convenience, and flexibility, (c) inspiration and possibilities for new ways to teach regardless of format, (d) for providing options for continuity during emergencies / pandemics, and (e) increased acceptance and adoption.

Experience did not change their perceptions of communication technologies
Other participants reported how their experience working and teaching from home during COVID did not change their perceptions either because they were already regular users of various communication technologies when they teach or because they still believe face-to-face / in-person communication cannot be replicated and/or because they believe learning at a distance is never as good as learning in person.

Some participants reported how their experience working and teaching from home during COVID led to increased concerns about issues of inequity, access, and support or their general dislike for teaching at distance. 


\section{Phase Two: Interview Results}

We conducted semi-structured interviews with 18 participants. The interviews were meant to elaborate on the survey questions and to provide additional insight into faculty perceptions of synchronous video-based communication technology. In many ways, the interviews simply supported the results and the themes that emerged from the survey. Below, we highlight the main themes that emerged from the interviews.

\section{Changes in Use of Synchronous Video-based Communication Technology During COVID-19}

Participants' use of synchronous video-based communication technology prior to COVID-19 varied greatly. While many described using it occasionally in their personal life (e.g., video chat with friends) or for work (e.g., collaborating with colleagues in another country), some described using it rarely or never. But all participants described how their use of it had increased during COVID-19, whether to talk to family, take part in meetings, hold office hours, or teach a course. Even veteran online teachers talked about adding additional synchronous meetings because as one described it, "students really like the opportunity [to connect] ...we still have this human desire to speak [to each other]." Others also expressed their excitement about the increased use of synchronous meetings at work. One participant explained how "it's no longer something that I am having to encourage my fellow faculty to be able to use."

\section{Strengths and Weaknesses of Synchronous Video-based Communication}

Participants all recognized and had experienced some strengths and weaknesses with synchronous video-based communication (many that were discussed earlier in this article). In terms of strengths, participants pointed to flexibility/convenience/accessibility. They also mentioned that it can improve interaction and promote community building (including getting to know each other's pets, for instance). Participants also indicated other benefits, such as being able to provide a "face-to-face" experience in real-time, facilitate meetings with varying group sizes, and improve group work/collaboration across the university or even the world. They also noted that these online meetings can usually be recorded for future reference or for those who could not attend, and that they can enable people to continue working even during a disaster or a pandemic. Some quotes stood out:

Gives us the ability to have the face-to-face real time communication that closely approximates the way that we would normally have conversations.

Helpful for people to learn names and a new organization because I've noticed, even from my now virtual book club, seeing everyone's names on the screen has been a helpful visual cue.

There is a humanization that happens that you can't get when you're not talking directly to somebody or speaking directly to somebody. It doesn't happen as well, or as much with asynchronous interaction. So, you get that real time interaction, you get the humanization.

However, participants were quick to identify some weaknesses of this type of communication. These included technical issues, dead silences/awkward pauses, access issues (broadband/technology), lack of body language as well as tendencies to keep webcams off, distraction, privacy issues, time zone constraints, lack of experience and familiarity with the tool, 
fatigue, and an intrusion on work life balance (which was exacerbated with entire families working from home together). The following remarks capture some of these ideas:

You just lose attention...

The kids talk less, they interact a lot less, so it requires a teacher to be so much more energetic and manipulative of technology...

I keep looking at my own video feed instead of staring at that camera which doesn't look like an eye to me, you know, and I think that can make it hard to pick up on social cues.

Most... use their mobile phone and the quality is totally different. While they're on the phones, they normally don't turn on their cameras. So, it's totally different in terms of how they learn and...the conversation.

\section{Experiences With and Strategies to Combat "Zoom Fatigue"}

A relatively new, yet widely experienced, side effect of taking part in synchronous meetings is what is now often referred to as "Zoom fatigue" or experiencing a "Zoom hangover" - that is, the feeling of being exhausted after a long synchronous meeting or back-toback shorter synchronous meetings. When fatigue came up as a weakness of synchronous videobased communication, we asked participants about their experiences with it and how they addressed it. Most participants acknowledged that they had, in fact, experienced Zoom fatigue. However, there was little consensus about the length of time required to experience this fatigue; it took just 1 hour for some to experience it and up to 11 hours for another. At the same time, a few participants had never experienced it. Participants noted that they proactively blocked off time before and after scheduled meetings, incorporated breaks or "stretch time" in longer prescheduled meetings, added interactivity (e.g., practice XYZ off-screen and come back to the meeting), observed a meeting moratorium day to recharge, extended the workday to accommodate breaks, turned off webcams, and prioritized some meetings over others. The following quotes capture some these sentiments:

Some people were very proud that they brought down their lecture from two hours to one hour, but for Zoom that's still quite a long time to be sitting and staring at a screen.

I think turning off that camera is helpful, because in some ways it functions in the same way...like in some meetings to people be like it's totally okay if you get up and walk around...it feels like being able to turn the camera off is a way of alleviating that zoom fatigue in some ways.

Here are, I think, some other ways that some of these providers are... helping you not to see your face as much because that we know that self-monitoring your own facial expressions can be really distracting.

\section{Synchronous Video-based Communication Technology Influencing Future Work}

Finally, we asked participants to reflect on how their experience using synchronous communication technology will influence how they do their job in the future. Nobody saw this 
technology drastically changing their job overnight. However, many did talk about how they expected more freedom and flexibility and research collaborations moving forward but also more synchronous meetings with colleagues and students. Others, though, also talked about how their experiences (and others) will likely help all of us use it more responsibly, in part by balancing our use of it but also by being aware of different aspects of netiquette as well as access. The following are quotations from various respondents on this topic.

I have a feeling we're going to have a lot more zoom based meetings in the future. I think it's going to give people more freedom and flexibility when it comes to meetings because we've seen that we can still do our work.

I'm expecting that the overall experience with zoom, not just mine, but in general. Will leave more flexibility for people to actually use it when it's appropriate... to really balance.

Our students lives even after the pandemic's over... will not be any less hectic than it was before.... So, this will be a convenient way to do office hours and hopefully connect with some more students that might be intimidated to come into one's office or just the office hours are not convenient for them.

I've discovered that I need to have more conversations like this with my students, I need to make the opportunity available.

\section{Discussion}

We began this study during the summer of 2020. At that point, while we were unsure what the future might bring, many signs suggested that the 2020-2021 academic year was going to be far from normal. As researchers of learning design and technology, we were interested in, and perhaps even a little nervous about, the sudden increased use of blended, remote, and online learning. There was a lot of initial press highlighting issues with using synchronous video-based communication (e.g., Lederman, 2020b; Setera, 2020; Strauss, 2020). Also, as mentioned earlier, many faculty members entered the pandemic with skeptical, if not completely critical, feelings about online learning. Given all of this, we were curious how faculty experiences working and teaching in these new formats might change not only how they teach but how they do other parts of their job moving forward.

The first research question focused on faculty perceptions of using synchronous videobased communication for personal use, teaching and learning, and for non-teaching work purposes. The data from this study were in some ways mixed. When specifically asked, participants reported being highly satisfied with synchronous video-based technology in their personal and work life and especially for work not focused on teaching (e.g., committee work, advising, research). This differed from many popular media stories that painted a much grimmer picture as well as previous research which suggested mixed or negative perceptions of using synchronous video-based communication technology (see Liu \& Alexander, 2017; Martin et al., 2020; Park \& Bonk, 2007).

However, when asked to explain their answers, the only consistent positive theme was that they liked the convenience and flexibility of synchronous video-based technology to connect with family, friends, students, and colleagues during the pandemic. On the other hand, they 
pointed out several problems they found with synchronous meetings, including overuse and fatigue, lack of engagement and distraction, a learning curve for many, technical issues, and overall misuse of the technology which align with previous research (Liu \& Alexander, 2017; Olson \& McCracken, 2015). Online educators also need to be aware that research suggests that challenges like these can be more common for students of color and lower-income students (Means \& Neisler, 2021).

The second research question focused on how faculty perceptions of communication technologies changed as during the COVID-19 pandemic. Most participants reported being the most satisfied with using email $(M=4.05)$, which is a little surprising given how often faculty members, in our experience, like to complain about email. Research has confirmed that email comprises a sizable portion of online teachers' workload and the perceived need to respond quickly to email can leave educators feeling "that there is no 'down' time for online teaching" (Payne McLain, p. 54, 2005). Students, however, reported that emails positively impacted their learning and motivation, even more so than other forms of communication, such recorded video messages (Conklin \& Garrett Dikkers, 2021).

After email, participants reported being more satisfied with synchronous meetings $(M=3.95)$ than they were with asynchronous text-based discussions $(M=3.78)$, thus, suggesting that faculty preference is not simply due to the asynchronous or synchronous nature of a communication technology but likely more how each is commonly used by faculty members. Most participants also reported that they were more likely to use synchronous video-based communication for work not related to teaching $(M=4.19)$ and for teaching a blended or online course $(M=4.06)$ than they were before the pandemic, thus suggesting that faculty perceptions of using synchronous sessions are improving.

Many described how being introduced to new communication technologies and/or gaining more experience during COVID-19 helped improve their confidence and comfort using communication technologies. Some even described how it inspired them to explore new ways of teaching and learning. Many, though, also pointed out that faculty members and students still have a lot to learn about how to effectively use this technology and therefore need additional training and support moving forward, which aligns with previous research like Olson and McCracken (2015). Future research and professional development should explore how online teachers can effectively blend synchronous and asynchronous learning activities (Olson \& McCracken, 2015). For instance, Olson and McCracken (2015) found that simply adding synchronous sessions to an asynchronous course is unlikely to improve learning outcomes; instructors need support on how to strategically blend synchronous and asynchronous learning activities. When providing faculty members with professional development opportunities it is important to consider not only the topics but also how the professional development will be facilitated. Professional development is more effective when facilitators are modeling what is being taught so that participants can experience the strategies as a student (Borup \& Evmenova, 2019). Universities - especially colleges of education - should also work to prepare their teacher education and doctoral students to teach online (Bishop-Monroe et al., 2021).

\section{Limitations}

The results from this study should not be generalized to all faculty. The majority of participants in this study taught in the field of education. The participants also self-selected to participate in this study, which could suggest that they either had very positive or negative experiences with synchronous video-based communication technology and/or teaching blended 
or online courses. The data for this study were collected early in the pandemic. Faculty perceptions could have changed, and still might change over time. Further, our findings are limited by the questions asked as well as limitations due to the qualitative data being analyzed by only one researcher.

\section{Conclusion}

The first online course was offered over 30 years ago (Harasim, 1987). However, despite the decades that have passed and advances in technology since, instructors and students largely interact in online courses in the same ways today as they did then, with asynchronous text-based communication. There is a good reason for this; asynchronous text-based communication has effectively enabled millions of students to learn online. The COVID-19 pandemic forced nearly every faculty member to work and teach from a distance and specifically to use a variety of communication technologies, including synchronous meetings, in ways they might not have before. We questioned how these new experiences might change faculty perceptions and, in turn, change online learning.

Our results suggest that faculty will use synchronous meetings more at work, both for teaching and nonteaching duties. Faculty members also will likely continue to explore additional ways to use synchronous meetings in their face-to-face, blended, and fully online courses, thus further blurring the lines between traditional face-to-face and online learning. However, additional research is needed to find out whether faculty in other disciplines as well as students share these same perspectives and desire for change. Consistent with our findings, the recently published Chloe Report suggests that synchronous video-based communication technology is gaining ground and is here to stay. Therefore, it is incumbent upon learning technologists like us to help guide, support, and study faculty members' use of it.

\section{Declarations}

The authors declared no potential conflicts of interest with respect to the research, authorship, and/or publication of this article.

The authors received approval from the ethics review board of Boise State University, USA for this study.

The authors received no financial support for the research, authorship, and/or publication of this article. 


\section{References}

Allen, E. I., \& Seaman, J. (2007). Online nation: Five years of growth in online education. Sloan-C.

Allen, I. E., \& Seaman, J. (2017). Digital compass learning: Distance education enrollment report 2017. Babson Survey Research Group.

Allen, E. I., Seaman, J., Lederman, D., \& Jaschik, S. (2012). Conflicted: Faculty and online education, 2012. Inside Higher Ed, Babson Survey Research Group and Quahog Research Group.

Bali, M. (2016). Bringing out the human in synchronous and asynchronous media for learning. In W. Kilgore (Ed.), Humanizing online teaching and learning. https://humanmooc.pressbooks.com/chapter/bringing-out-the-human-in-synchronous-andasynchronous-media-for-learning/

Bali, M., \& Meier, B. (2014, March 4). An affinity for asynchronous learning. Hybrid Pedagogy. https://hybridpedagogy.org/affinity-asynchronous-learning/

Belt, E. \& Lowenthal, P. R. (2021). Video use in online and blended courses: A qualitative synthesis. Distance Education, 42(3), 410-440. https://doi.org/10.1080/01587919.2021.1954882

Bishop-Monroe, R., Di Paulo Harrison, B., Knight, M. E., Corritore, C., Rybarczyk, B. J., \& Stewart York, A. (2021). Preparing doctoral students to teach in an increasingly virtual world: A response to COVID-19 and beyond. Online Learning, 25(1), 166-181.

http://dx.doi.org/10.24059/olj.v25i1.2446

Bolliger, D. U., \& Martin, F. (2018). Instructor and student perceptions of online student engagement strategies. Distance Education, 39(4), 568-583.

https://doi.org/10.1080/01587919.2018.1520041

Borup, J., \& Evmenova, A. (2019). The effectiveness of professional development in overcoming obstacles to effective online instruction in a college of education. Online Learning, 23(2), 1-20. https://doi.org/10.24059/olj.v23i2.1468

Bower, B. L., \& Hardy, K. P. (2004). From correspondence to cyberspace: Changes and challenges in distance education. New Directions for Community Colleges, 2004, 5-12. http://dx.doi.org/10.1002/cc.169

Caines, A. (2020, December). The Zoom Gaze. https://reallifemag.com/the-zoom-gaze/

Casey, D. M. (2008). A journey to legitimacy: The historical development of distance education through technology. TechTrends, 52, 45-51. https://doi.org/10.1007/s11528-008-0135-Z

Clark, C., Strudler, N., \& Grove, K. (2015). Comparing asynchronous and synchronous video vs. text-based discussions in an online teacher education course. Online Learning, 19(3), 48-70. http://dx.doi.org/10.24059/olj.v19i3.668 
Conklin, S., \& Garrett Dikkers, A. (2021). Instructor social presence and connectedness in a quick shift from face-to-face to online instruction. Online Learning, 25(1), 135-150.

http://dx.doi.org/10.24059/olj.v25i1.2446

Cornelius, S. (2014). Facilitating in a demanding environment: Experiences of teaching in virtual classrooms using web conferencing. British Journal of Educational Technology, 45(2), 260-271. https://doi.org/10.1111/bjet.12016

Craig, R. (2020, April). What students are doing is remote learning, not online learning. There's a difference. EdSurge. https://www.edsurge.com/news/2020-04-02-what-students-are-doing-isremote-learning-not-online-learning-there-s-a-difference

de Oliveira Dias, M., Lopes, R. D. O. A., \& Teles, A. C. (2020). Will virtual replace classroom teaching? Lessons from virtual classes via Zoom in the times of COVID-19. Journal of Advances in Education and Philosophy, 4(05), 208-213. http://dx.doi.org/10.36348/jaep.2020.v04i05.004

Elo, S., Kääriäinen, M., Kanste, O., Pölkki, T., Utriainen, K., \& Kyngäs, H. (2014). Qualitative content analysis: A focus on trustworthiness. SAGE Open.

https://doi.org/10.1177/2158244014522633

Ertmer, P. A. (1999). Addressing first- and second-order barriers to change: Strategies for technology integration. Educational Technology Research and Development, 47(4), 47-61. https://doi.org/10.1007/BF02299597

Finkelstein, J. E. (2006). Learning in real time: Synchronous teaching and learning online. Jossey-Bass.

Flaherty, C. (2020, April). Zoom Boom. Inside HigherEd. https://www.insidehighered.com/news/2020/04/29/synchronous-instruction-hot-right-now-itsustainable

Garrison, D. R., Anderson, T., \& Archer, W. (1999). Critical inquiry in a text-based environment: Computer conferencing in higher education. Internet and Higher Education, 2(23), 87-105. https://doi.org/10.1016/S1096-7516(00)00016-6

Garrison, R. (2009). Implications of online learning for the conceptual development and practice of distance education. Journal of Distance Education, 23(2), 93-104.

Graham, C. R. (2006). Blended learning systems: Definition, current trends, and future directions. In C. J. Bonk \& C. R. Graham (Eds.), Handbook of blended learning: Global perspectives, local designs (pp. 3-21). Pfeiffer Publishing.

Grant, M. M., \& Cheon, J. (2007). The value of using synchronous conferencing for instruction and students. Journal of Interactive Online Learning, 6(3), 211-226. 
Gray, J. A., \& DiLoreto, M. (2016). The effects of student engagement, student satisfaction, and perceived learning in online learning environments. NCPEA International Journal of Educational Leadership Preparation, 11(1), 98-119.

Harasim, L. (1987). Teaching and learning on-line: Issues in computer-mediated graduate courses. Canadian Journal of Educational Communication, 16(2), 117-135. http://dx.doi.org/10.21432/T2TK6K

Harasim, L. (2000). Shift happens: Online education as a new paradigm in learning. Internet and Higher Education, 3, 41-61. http://dx.doi.org/10.1016/S1096-7516(00)00032-4

Hodges, C., Moore, S., Lockee, B., Trust, T., \& Bond, A. (2020, March). The difference between emergency remote teaching and online learning. EDUCAUSE Review.

https://er.educause.edu/articles/2020/3/the-difference-between-emergency-remote-teaching-andonline-learning

Hrastinski, S. (2008). The potential of synchronous communication to enhance participation in online discussions: A case study of two e-learning courses. Information \& Management, 45(7), 499-506. http://dx.doi.org/10.1016/j.im.2008.07.005

Hrastinski, S., Keller, C., \& Carlsson, S. A. (2010). Design exemplars for synchronous elearning: A design theory approach. Computers \& Education, 55(2), 652-662. http://dx.doi.org/10.1016/j.compedu.2010.02.025

Huang, X., \& Hsiao, E. L. (2012). Synchronous and asynchronous communication in an online environment: Faculty experiences and perceptions. Quarterly Review of Distance Education, 13(1), 15-30.

Hunt, H. D., Davies, K., Richardson, D., Hammock, G., Akins, M., \& Russ, L. (2014). It is (more) about the students: Faculty motivations and concerns regarding teaching online. Online Journal of Distance Learning Administration, 17(2), 62-71.

https://www.westga.edu/ distance/ojdla/summer172/Hunt_Davies_Richardson_Hammock_Akin s_Russ172.html

Jaschik, S., \& Lederman, D. (2016). The 2016 Inside Higher Ed survey of faculty attitudes on technology. Inside Higher Ed \& Gallup. https://www.insidehighered.com/booklet/2016-surveyfaculty-attitudes-technology

Kim, J. (2020, April). Teaching and learning after COVID-19. Inside HigherEd. https://www.insidehighered.com/digital-learning/blogs/learning-innovation/teaching-andlearning-after-covid-19

Lederman, D. (2018, November). Online education ascends. Inside Higher Ed. https://www. insidehighered.com/digital-learning/article/2018/11/07/new-data-online-enrollments-growandshare-overall-enrollment 
Lederman, D. (2020a, March). The shift to remote learning: The human element. Inside HigherEd. https://www.insidehighered.com/digital-learning/article/2020/03/25/how-shiftremote-learning-might-affect-students-instructors-and

Lederman, D. (2020b, March). Will shift to remote teaching be boon or bane for online learning? Insider HigherEd. https://www.insidehighered.com/digital-learning/article/2020/03/18/mostteaching-going-remote-will-help-or-hurt-online-learning

Leech, N. L., \& Onwuegbuzie, A. J. (2007). An array of qualitative data analysis tools: A call for data analysis triangulation. School Psychology Quarterly, 22(4), 557-584. https://doi.org/10.1037/1045-3830.22.4.557

Lemos dos Santos, H., \& Cechinel, C. (2019). The final year project supervision in online distance learning: assessing students and faculty perceptions about communication tools, Behaviour \& Information Technology, 38(1), 65-84. https://doi.org/10.1080/0144929X.2018.1514423

Liu, J. C., \& Alexander, R. (2017). Factors affecting faculty use of video conferencing in teaching: A mixed-method study. Journal of Educational Technology Development and Exchange, 10(2), 37-54. http://dx.doi.org/10.18785/jetde.1002.03

Lloyd, S. A., Byrne, M. M., \& McCoy, T. S. (2012). Faculty-perceived barriers of online education. Journal of online learning and teaching, 8(1). https://jolt.merlot.org/vol8no1/1loyd 0312.pdf

Lowenthal, P. R. (under review). Does video improve social presence? Exploring student perceptions of asynchronous video in online courses.

Lowenthal, P. R. (2010). The evolution and influence of social presence theory on online learning. In T. T. Kidd (Ed.), Online education and adult learning: New frontiers for teaching practices (pp. 124-139). IGI Global.

Lowenthal, P. R. (2021). Video feedback: Is it worth the effort? A response to Borup et al. Educational Technology Research and Development, 63, 161-184. https://doi.org/10.1007/s11423-020-09872-4

Lowenthal, P. R., Borup, J., West, R. E., \& Archambault, L. (2020). Thinking beyond Zoom: Using asynchronous video to maintain connection and engagement during the COVID-19 pandemic. Journal of Technology and Teacher Education, 28(2), 383-391.

Lowenthal, P. R., Dunlap, J. C., \& Snelson, C. (2017). Live synchronous web meetings in asynchronous online courses: Reconceptualizing virtual office hours. Online Learning, 21(4), http://dx.doi.org/10.24059/olj.v21i4.1285

Lowenthal, P. R., Fiock, H. S., Shreaves, D., \& Belt, E. (under review). Investigating students' perceptions of screencasting style of video feedback in online courses. 
Lowenthal, P. R., \& Moore, R. (2020). Exploring student perceptions of Flipgrid in online courses. Online Learning, 24(4), 28-41. https://doi.org/10.24059/olj.v24i4.2335

Olson, J. S., \& McCracken, F. E. (2015). Is it worth the effort? The impact of incorporating synchronous lectures into an online course. Online Learning, 19(2), http://dx.doi.org/10.24059/olj.v19i2.499

McDaniels, M., Pfund, C., \& Barnicle, K. (2016). Creating dynamic learning communities in synchronous online courses: One approach from the Center for the Integration of Research, Teaching and Learning (CIRTL). Online Learning, 20(1), 110-129. http://dx.doi.org/10.24059/olj.v20i1.518

McDonald, D. (2016). Asynchronous vs. synchronous communication in the online classroom. Wiley Educational Services. https://ctl.wiley.com/asynchronous-vs-synchronouscommunication-in-the-online-classroom/

McGee, P., Windes, D., \& Torres, M. (2017). Experienced online instructors: Beliefs and preferred supports regarding online teaching. Journal of Computing in Higher Education, 29(2), 331-352. http://dx.doi.org/10.1007/s12528-017-9140-6

McMurtie, B. (2021, May). Online, everyone is in the front row. The Chronicle of Higher Education. https://www.chronicle.com/newsletter/teaching/2021-05-27

Mansbach, J., \& Austin, A. E. (2018). Nuanced perspectives about online teaching: Mid-career and senior faculty voices reflecting on academic work in the digital age. Innovative Higher Education, 43(4), 257-272. http://dx.doi.org/10.1007/s10755-018-9424-4

Martin, F., \& Parker, M. A. (2014). Use of synchronous virtual classrooms: Why, who, and how. Journal of Online Learning and Teaching, 10(2), 192-210.

Martin, F., Polly, D., \& Ritzhaupt, A. (2020, September). Bichronous online learning: Blending asynchronous and synchronous online learning. EDUCAUSE Review. https://er.educause.edu/articles/2020/9/bichronous-online-learning-blending-asynchronous-andsynchronous-online-learning

Mayadas, F. (1997). Asynchronous learning networks: A Sloan Foundation perspective. Journal of Asynchronous Learning Networks, 1(1), 1-16. http://dx.doi.org/10.24059/olj.v1i1.1941

Means, B., \& Neisler, J. (2021). Teaching and learning in the time of COVID: The student perspective. Online Learning, 25(1), 8-27. https://doi.org/10.24059/olj.v25i1.2496

Miles, M. B., \& Huberman, A. M. (1994). Qualitative data analysis: An expanded sourcebook. Sage. 
Moore, M. G. (1989). Three types of interaction. [Editorial]. American Journal of Distance Education, 3(2), 1-6.

Moore, J. L., Dickson-Deane, C., \& Galyen, K. (2011). e-Learning, online learning, and distance learning environments: Are they the same? Internet and Higher Education, 14(2), 129-135. http://dx.doi.org/10.1016/j.iheduc.2010.10.001

Norton, P., \& Hathaway, D. (2015). Teachers' online experience: Is there a covert curriculum in online professional development? Journal of Technology and Teacher Education, 23(4), 509533.

Olson, J., \& McCracken, F. (2014). Is it worth the effort? The impact of incorporating synchronous lectures into an online course. Online Learning, 19(2). http://dx.doi.org/10.24059/olj.v19i2.499

Onwuegbuzie, A. J., \& Leech, N. L. (2005). Taking the "Q" out of research: Teaching research methodology courses without the divide between quantitative and qualitative paradigms. Quality \& Quantity, 39, 267-296. http://dx.doi.org/10.1007/s11135-004-1670-0

Oztok, M., Zingaro, D., Brett, C., \& Hewitt, J. (2013). Exploring asynchronous and synchronous tool use in online courses. Computers \& Education, 60(1), 87-94.

https://doi.org/10.1016/j.compedu.2012.08.007

Palloff, R. M., \& Pratt, K. (1999). Building learning communities in cyberspace: Effective strategies for the online classroom. Jossey-Bass.

Park, Y. J., \& Bonk, C. J. (2007). Synchronous learning experiences: Distance and residential learners' perspectives in a blended graduate course. Journal of Interactive Online Learning, 6(3), 245-264.

Parker, M., \& Martin, F. (2010). Using virtual classrooms: Student perceptions of features and characteristics in an online and a blended course. Journal of Online Learning and Teaching, 6(1), 135-147.

Payne McLain, B. (2005). Estimating faculty and student workload for interaction in online graduate music courses. Online Learning, 9(3), 47-56. http://dx.doi.org/10.24059/olj.v9i3.1784

Peterson, A., Beymer, P., \& Putnam, R. (2019). Synchronous and asynchronous discussions: Effects on cooperation, belonging, and affect. Online Learning, 22(4).

http://dx.doi.org/10.24059/olj.v22i4.1517

Poll, K., Widen, J., \& Weller, S. (2014). Six instructional best practices for online engagement and retention. Journal of Online Doctoral Education, 1(1), 56-72.

Pokhrel, S., \& Chhetri, R. (2021). A literature review on impact of COVID-19 pandemic on teaching and learning. Higher Education for the Future, 8(1), 133-141. 
Roe, D. (2020, May) Why remote learning and online earning are not the same. CMS Wire. https://www.cmswire.com/learning-development/why-remote-learning-and-online-learning-arenot-the-same/

Romero-Hall, E., \& Vicentini, C. R. (2017). Examining distance learners in hybrid synchronous instruction: Successes and challenges. Online Learning Journal, 21(4).

http://dx.doi.org/10.24059/olj.v21i4.1258

Schaberg, C. (2018, March). Why I won't teach online. Inside HigherEd. https://www.insidehighered.com/digital-learning/views/2018/03/07/professor-explains-why-hewont-teach-online-opinion

Schaberg, C. (2020, September). Why I'm teaching online. Insider HigherEd. https://www.insidehighered.com/views/2020/09/11/professor-who-asserted-hed-never-teachonline-explains-why-hes-opting-do-so-now

Schulman, C. (2020, April). I used to shut my windows to New York's noise. Now I long for a honking horn. Washington Post. https://www.washingtonpost.com/outlook/2020/04/09/newyork-silent-coronavirus/

Seaman, J. E., Allen, I. E., \& Seaman, J. (2018). Grade increase: Tracking distance education in the United States. Babson Survey Research Group.

Sener, J. (2015, July). Updated e-learning definitions. OLC Insights. https://onlinelearningconsortium.org/updated-e-learning-definitions-2/

Setera, K. (2020, March). FBI warns of teleconferencing and online classroom hijacking during COVID-19 Pandemic. FBI. https://www.fbi.gov/contact-us/field-offices/boston/news/pressreleases/fbi-warns-ofteleconferencing-and-online-classroom-hijacking-during-covid-19pandemic

Stewart, W. (2021). A global crash-course in teaching and learning online: A thematic review of empirical Emergency Remote Teaching (ERT) studies in higher education during Year 1 of COVID-19. Open Praxis, 13(1), 89-102. http://dx.doi.org/10.5944/openpraxis.13.1.1177

Strauss, V. (2020, April). School districts, including New York City's, start banning Zoom because of online security issues. Washington Post. https://www.washingtonpost.com/education/2020/04/04/school-districts-includingnew-yorkcitys-start-banning-zoom-because-online-security-issues/

Themelis, C. (2014). Synchronous video communication for distance education: The educators' perspective. Open Praxis, 6(3), 245-256. http://dx.doi.org/10.5944/openpraxis.6.3.128

Saba, F. (2011). Distance education in the United States: Past, present, future. Educational Technology, 51, 11-18. 
Ubell, R. (2017, January). Why faculty still don't want to teach online. OLC Insights. https://onlinelearningconsortium.org/faculty-still-dont-want-teach-online/

West, R., \& Borup, J. (2021, February). The power of asynchronous video. EDUCAUSE Review. https://er.educause.edu/blogs/2021/2/the-power-of-asynchronous-video 


\section{Appendix A}

Survey and Instrument Questions

\section{Phase One Survey Questions}

\section{Demographic Questions}

How many years have you taught in higher education?

How many years have you taught blended or online courses in higher education?

Prior to the COVID-19 pandemic, how satisfied were you with teaching blended or online courses in higher education?

Prior to the COVID-19 pandemic, how frequently did you with using live synchronous videobased communication:

-Personal life

$$
\text { [Daily -- Never] }
$$

-Teaching traditional face-to-face courses

-Teaching and learning blended and online courses

-Work not related to teaching and learning (e.g., research collaboration, advising, committee work)

\section{Survey Questions}

1. Currently, how satisfied are you with using synchronous video-based communication (e.g., Zoom, WebEx) in your personal life (e.g., talking with friends or family)?

$$
\text { [ (1) Very Dissatisfied --- Very Satisfied (5) ] }
$$

2. Currently, how satisfied are you with using synchronous video-based communication (e.g., Zoom, WebEx) for teaching and learning?

$$
\text { [ (1) Very Dissatisfied --- Very Satisfied (5) ] }
$$

3. Currently, how satisfied are you with using synchronous video-based communication (e.g., Zoom, WebEx) for work not related to teaching and learning (e.g., research collaboration, advising, committee work)?

$$
\text { [ (1) Very Dissatisfied --- Very Satisfied (5) ] }
$$

4. Please briefly explain why you answered these three previous questions the way that you did.

5. Currently, how satisfied are you with using the following communication methods when teaching blended or online courses?

[Don't currently used - Extremely dissatisfied --- Extremely satisfied]

--Email

--Phone call

--Text message (to one person)

--Group text or message (e.g., Slack)

--Asynchronous text-based discussions (e.g., Learning Management System like Blackboard or Canvas) 
--Asynchronous video-based discussions (e.g., Flipgrid, VoiceThread)

--Synchronous video-based discussions (e.g., Zoom, WebEx)

6. To what degree do you agree with the following, once the COVID-19 pandemic ends:

\section{[ (1) Strongly Disagree --- Strongly Agree (5) ]}

--If is up to me, I am more likely to use synchronous video-based communication (e.g., Zoom, WebEx) for meetings at work?

--If it is up to me, I am more likely to use synchronous video-based communication (e.g.,

Zoom, WebEx) when teaching a fully online course?

--if it is up to you, I am more likely to use synchronous video-based communication (e.g., Zoom, WebEx) for teaching a traditional face-to-face course?

7. Please briefly explain why you answered these three previous questions the way that you did.

8. How has your experience working and teaching from home during the COVID-19 pandemic influenced or changed your perceptions of using communication and learning technologies in general for teaching at a distance (e.g., emergency remote learning, distance learning, online learning)?

\section{Additional Comments}

\section{Phase Two Interview Questions}

1. What are the strengths and weaknesses of using this type of communication technology?

2. Describe how you used synchronous communication technology (e.g., Zoom) prior to the COVID-19 pandemic and has your use changed during the COVID-19 pandemic?

3. Have you ever experienced "Zoom fatigue" or something similar? How have you adjusted your work/teaching to address this?

Do you expect your experience using synchronous communication technology (e.g., Zoom) will influence how you do your job, whether teaching or non-teaching, in the future? 